This item was submitted to Loughborough's Research Repository by the author.

Items in Figshare are protected by copyright, with all rights reserved, unless otherwise indicated.

\title{
World cities and the uneven geographies of financialization: unveiling stratification and hierarchy in the world city archipelago
}

\section{PLEASE CITE THE PUBLISHED VERSION}

https://doi.org/10.1111/1468-2427.12344

\section{PUBLISHER}

Wiley @ U Urban Research Publications Limited

\section{VERSION}

AM (Accepted Manuscript)

\section{PUBLISHER STATEMENT}

This work is made available according to the conditions of the Creative Commons Attribution-NonCommercialNoDerivatives 4.0 International (CC BY-NC-ND 4.0) licence. Full details of this licence are available at: https://creativecommons.org/licenses/by-nc-nd/4.0/

\section{LICENCE}

CC BY-NC-ND 4.0

\section{REPOSITORY RECORD}

Van Meeteren, Michiel, and David Bassens. 2019. "World Cities and the Uneven Geographies of Financialization: Unveiling Stratification and Hierarchy in the World City Archipelago". figshare. https://hdl.handle.net/2134/37046. 


\title{
World cities and the uneven geographies of financialization: Unveiling stratification and hierarchy in the world city archipelago
}

\author{
Michiel van Meeteren ${ }^{1}$, David Bassens ${ }^{2,3}$ \\ Published as: van Meeteren, M., \& Bassens, D. (2016). World cities and the uneven geographies of \\ financialization: Unveiling stratification and hierarchy in the world city archipelago. International \\ Journal of Urban and Regional Research, 40(1), 62-81.
}

Please refer to the published version.

\section{Abstract}

This paper critically evaluates the network-centrism of much of contemporary world cities research and queries its limits to unveil key accumulation processes under financialized globalization. Our object of inquiry is the world city archipelago (WCA), a material, yet noncontiguous space of world city 'islands', which is (re)produced through the sociospatial practices in advanced producer services (APS) as they assist in constructing (financial) accumulation strategies for their clients. Scrutinizing the WCA with a singular focus on networks can veil dynamics that lead to internal stratification and hierarchy between world cities and their constitutive outside. Alternatively, these veiled dimensions are better grasped by territorial, scalar, and place-based abstractions. As an example, we unveil WCA space by studying the space of practice of APS practices in three recent cases of Eurobond issuance. By comparing these three instances through an encompassing approach, a bounded geography of a financialized accumulation space is identified, which contains London and other world cities as a necessary space of dependence, but also stretches out to various contingent spaces of engagement at the fringes of the WCA network: offshore jurisdictions and places of debt origination. We conclude by making the case for a heightened sensitivity for core-periphery structures that exist between the WCA and its outside, but also within the WCA itself.

Keywords: world cities, global cities, socio-spatial relations, financialization, critical realism, TSPN, Eurobonds

\section{Acknowledgement}

Both authors have contributed equally to this paper and share equal responsibility for the arguments here formulated.

\footnotetext{
${ }^{1}$ Ghent University - Geography Department - Krijgslaan 281 S8, 9000 Ghent - Belgium

${ }^{2}$ Vrije Universiteit Brussel - Geography Department - Pleinlaan II, 1050 Brussel - Belgium

${ }^{3}$ Corresponding author
} 


\section{Introduction: World cities and financial circuits of value}

Chair: [Y]ou filed, in Companies House, losses for most of the years that you have been running coffee houses in the UK. [...] Yet $[\ldots]$ the unit enjoyed operating profit margins of $15 \%$. How do you reconcile those two?

Troy Alstead: We know that we must be in the UK to be a successful global company.

Austin Mitchell: I have been putting on weight drinking enormous quantities of caramel macchiato and you've been losing money on it. It really is incompetent. Either that, or it is the money you are taking out through the $6 \%$ royalty. $[\ldots]$

Meg Hillier: Why is it that $75 \%$ of the world's coffee is traded through Switzerland? Is there a favorable tax rate for doing that?

Troy Alstead: [...] The full $6 \%$ goes to our regional headquarters in Amsterdam. That is where we have a roasting facility, and all the regional headquarters for our Europe, Middle East and Africa businesses are headquartered in Amsterdam.

Troy Alstead: Part of that is history. Long before Starbucks put our coffee buying in

Switzerland, that was true. Yes, around coffee trading and trading houses in general, Switzerland offers a very competitive tax rate, which certainly complements that activity. 
These excerpts from a UK parliamentary hearing by the Public Accounts Committee ${ }^{4}$ provide a rare occasion where a contemporary geography of capital accumulation is - at least partly - unveiled. Starbucks' coffee selling activities in the UK incurred years of strange consecutive losses, despite the British appetite for Starbucks' products even among British members of parliament. These losses suddenly become less puzzling when the intertwinements of the circuits of value beyond the UK market come into focus. How 'bucks' are being made on 'caramel macchiatos' hinges on an industrial circuit of coffee processing and R\&D running through the Netherlands and a merchant circuit of buying coffee reaching out to small-staffed offices in Switzerland. Switzerland is famous for 'a long history in coffee trade' despite its rather difficult accessibility for ships that actually transport coffee. In both circuits, hefty cost-maximizing royalties are induced in return for scarcely any material or intellectual labor. Starbucks' corporate structure and location choice is steeped by financial strategies to keep shareholders satisfied, at the expense of the UK Treasury. The supporting geographies of regulatory arbitrage draw on clever territorial combinations that allows for optimizing gains on coffee-selling activities. Financial circuits are constructed so that profits become mobile and are moved out of reach to places where hardly any activity takes place but taxation levels are 'competitive'. On the other side of the balance sheet, labor and production costs are fixed in the UK amounting to startling local losses for Starbucks. Needless to say, the profits in Switzerland would be a lot lower if British consumers were seduced less by sugared caffeinated hot beverages. Consumers remain necessary for actual profits to be made.

This Starbucks vignette draws renewed attention to the actors that actually create these legal geographies of accumulation. In the case above, Starbucks depended on Deloitte Touche Tohmatsu's tax services department to facilitate regulatory arbitrage and transfer pricing schemes (Financial Times, 2014). Global accountants and other Advanced Producer

\footnotetext{
4 Hearing (HC 716) of Starbucks CFO Troy Alstead (http://www.publications.parliament.uk/pa/cm201213/cmselect/cmpubacc/716/121112.htm).
} 
Services (APS) firms, whose corporate geographies form the empirical heart of the world cities research agenda (Taylor and Derudder, 2015), are fundamentally implicated in the production of increasingly complex financial solutions for client transnational corporations (TNCs) wishing to please shareholders as they feel the gaze of global financial markets (Froud et al., 2006; Palan et al. 2010; Wójcik, 2013a; Coe et al., 2014). Hence, world cities become 'obligatory passage points' under financialized globalization (Bassens and van Meeteren, 2014; cf. Allen, 2010). As realization of 'normal profits' is increasingly difficult in a condition of overaccumulation, TNC's become dependent on the expertise of financial intermediaries (e.g. investment banks) and auxiliary business services (accountants, law firms, management consultants, etc.), which do fee-based work (Bassens and van Meeteren, 2014). Therefore, additionally to facilitating 'classic' globalization strategies of re-organizing global production networks (Castells, 1989; Friedmann, 1986; Parnreiter, 2010), servicing the offshore world and enabling regulatory arbitrage is the veiled 'dark side' of world cities and their APS complexes (cf. Wojcik, 2013a, 2013b). APS acting from world cities are instrumental in orchestrating uneven development under financialized globalization.

As geographers, this shift in character of accumulation strategies challenges the spatialanalytic apparatus by which we detect, map and scrutinize these strategies. Transnational accumulation processes, exemplified in the Starbucks case, clearly cannot be grasped through the partial perspective of the national scale, which was long considered the 'natural' scale of analysis (Taylor, 2004; 2013). To make transnational capitalism visible, world city researchers in the late 1990s proposed to shift the metageographical perspective from 'mosaics to networks' (Beaverstock et al. 2000). Drawing heavily on Castells' $(1989,2000 a)$ notion of a transnational 'space of flows', world city research questioned the national scale as the dominant scale for economic development. Instead, it conceptualized the notion of a World City Archipelago (WCA) from which capitalist command and control is exercised over the world, yet operationalized this mostly through specifying, measuring, and mapping the 
world city network supported by global APS firms (Beaverstock et al. 2000; Taylor, 2004; cf. Parnreiter, 2014). An open question in world city research, indebted to its world-systems analysis heritage, regards the extent to which this WCA forms 'the core' of the contemporary capitalist world-system (Brown et al., 2010, cf. Jones, 1998). An assessment of the 'coreness' of the WCA could form an entry point to understand peripheralization and uneven development elsewhere. While we see no reason to fold our spatial conceptual apparatus back to the straightjacket of national scales, our central argument is that a singular networked reading of the WCA - as offered in Castells-inspired world city approaches - is insufficient to critically appreciate processes of peripheralization through financialization emerging from the WCA. More specifically, network-centrism (Jessop et al., 2008) can hide stratification in the WCA that socio-spatial practices of APS firms produce. As APS workers engage in 'applied economic geography' to socially construct material circuits of value (Lee, 2002), they collectively produce the WCA as a place, a scale, a territory and a network. Recapitulating the Starbucks case, making financialized accumulation work draws on practices that unlock the properties of territory (i.e. the role of offshore jurisdictions, cf. Sassen, 2008), place (i.e. the coding of the UK as a key market, see Massey, 2007), and scale (i.e. the ongoing legitimization of tax evasion in the face of parliamentary scrutiny).

Socio-spatial stratification within the WCA can be unveiled through differentiating between necessary and contingent spaces as they are crosscut by financial circuits of value. In this paper, we will illustrate our procedure of unveiling WCA space by scrutinizing role of APS in the creation of 'eurodebts' for corporate clients. Complementary to the emblematic surplusoptimizing Starbucks case, debt construction constitutes another financialized moment in the capital accumulation process. As for Castells (2000a: 106), 'the globalization of financial markets is the backbone of the global economy' driven by a networked logic, revealing the relevance of the other socio-spatial abstractions in financial market construction lends credibility to our argument by being a least-likely case (Gerring, 2007). Euromarkets, as 
circuits to circumvent (inter)nationally enforced capital mobility restrictions, contradict the assumption of a pure networked logic of contemporary finance. Below it will become apparent that Euromarkets fundamentally hinge on properties of territory, place, and scale, while the accommodating fee-based financial circuits are imbued with dependent power relations between centers of debt origination and a number of key world cities.

The remainder of the paper is structured as follows. The next section reviews how Manual Castells' network-centrism undergirds blind spots regarding hierarchy and stratification in world city research and offers a geographical methodology that could guide a more comprehensive view. The subsequent section then elaborates on the perspectives of Territory, Scale, Place, and Network (TSPN) (Jessop et al., 2008) and provides indications how they can elucidate our understanding of stratification in the WCA. Hereafter, we comparatively map three cases of Eurobond issuance, which is interpreted through TSPN in the section afterwards. We conclude with a reflection on how the TSPN approach allows a (re)connection of theories on world-city formation to the changing political economy under financialized globalization.

\section{Critique: Network-centrism in the world city archipelago}

Taylor's (2004; Taylor and Derudder, 2015) World City Network describes functional relations between world cities through the metaphor of an archipelago (the WCA). The archipelago projects a space as a collection of non-contiguous interconnected 'islands' with properties available at the inside, but scarce or inexistent at its outside (cf. Veltz, 1996; Graham and Marvin, 2001). The archipelago is a metaphor since there are not necessarily islands and water involved, but nevertheless, the spatial properties it projects are an abstraction denoting a real geography of difference (cf. Jonas, 1994; Sayer, 2000: 35-40). In the WCA, the nodes are cities that contain the APS spaces of practice (Watson and Beaverstock, 2014), while the dyads are the flows of information, goods, capital and people between these nodes. Here, Taylor and Derudder (2015) follow Castells' (2000a, 2000c) description of cities as anchoring 
points within the space of flows, although the archipelago metaphor has older antecedents in world city research. In his historical analysis of capitalism and world-cities, Braudel (1984: $30)^{5}$ observes that the world-city metropolis, the apex of the city system, such as Amsterdam and London at their time of hegemony, needed other subordinate cities to ensure accumulation of capital. This gave rise to a hierarchical archipelago of cities, with a clear center, in a 'sea' of subsistence livelihoods. Brown et al. (2010), hypothesize a similar role of contemporary world cities as they orchestrate the surplus creation and appropriation that is inherent in the core- and periphery-producing activities within the world-system (cf. Arrighi and Drangel, 1986). Initially, in his 1980 s work on the space of flows, Castells $(1983,1989)$ was also quite explicit that networked capitalist development created uneven, 'hierarchical' relations between places through a spatial division of labour.

However, it is mostly Castells' later re-interpretation of the space of flows that informs important strands of world cities research today (e.g., Taylor et al., 2010; Taylor and Derudder, 2015). In our view, this reliance on the 'later Castells', who is strongly influenced by complexity theory (Stalder, 2006), runs the risk of veiling the internal stratification and hierarchy within the WCA (see Parnreiter, 2014, for an assessment of a partially analogous evolution within Peter Taylor's work). First, Castells' (2000a, 2000c, 2000d) notion that 'the global city' is a network of non-contiguous sites that collectively perform a pre-programmed function, runs the danger of obscuring agency from their (re)production. Castells considers the financial districts of New York, London and Tokyo part of the same city. They work symbiotically, and the APS workers within them just do the job logically demanded from them by a preprogrammed structure (Castells, 2001, cited in Stalder 2006: 132-133, cf. Castells 2000c). In fact, for Castells (2000b: 374) 'the global financial markets, and their networks of management are the actual collective capitalist and the mother of all accumulations'. This

\footnotetext{
${ }^{5}$ Braudel borrows the expression from early 20th century historian Richard Häpke. Braudel's accumulation model also exhibits strong resemblance to Andre Gunder Frank's (1966) nested hierarchy of metropoles and satellites.
} 
depiction of global financial markets as a faceless collective capitalist automaton made up of financial flows and operated by electronic networks has been strongly criticized (see Friedmann, 2000; Marcuse, 2002; Jessop, 2003; Stalder, 2006) and it is difficult to not read it as an account of covert functionalism (e.g. Castells 2000c: 15-17, cf. Friedmann, 2000). Conceptualized as the effect of a complex system with unintended consequences, the WCA becomes a reified absolute space that merely executes the 'whirlwind' of virtualized financial capitalism (see Christophers, 2009, for a complementary critique).

Second, the amalgamated and networked conception of the global city, while useful for understanding the simultaneity, fluidity and interconnectedness of globalization, may veil social hierarchy inherent in capitalist accumulation (Cox, 2013), which generally translates in spatially uneven development (cf. Smith, 2008 [1984]). While it is an open empirical question whether capitalism was less hierarchical in the 1990s than today, surely the heightened relevance of financial processes increasingly articulates hierarchy within the WCA. Individual world cities differ in their degree of 'strategicness' (Taylor et al., 2014) for the operation of global financial markets. For instance, the concentration of financial knowledge, assets and sunk costs in London is so high that the whole WCA as we know it would cease to be (Clark, 2002, cf. Massey, 2004). A similar argument can be made for the dyad London-New York (Wójcik, 2013b). However, to what extent would similar reasoning apply to London-Frankfurt (Faulconbridge, 2004), London-Dubai (Bassens, 2013) or London-Moscow? In our view, the answer implies stratification: some dyads are more important than others for actors in the WCA to make it an obligatory passage point (Allen, 2010) under financialized globalization. Implicitly acknowledging these issues in their latest world city treatise, Taylor and Derudder (2015: 8) promote the notion of 'a network with hierarchical tendencies'. This treatment is closer again to the formulation of the 1980s Castells, but retains a primary focus on networks. 
Yet, even such a careful specification of the WCA as an empirical reflection of networked social practices seems insufficient to explain how space is structured informally in absence of formal coordination in the modern world-system (cf. Sassen, 2013). Stressing the fluidity of work practices in networked readings of the WCA makes it hard to explain its surprising geographic stability over the past few decades, despite massive geo-economic changes (Derudder et al., 2012). Instead, we propose to designate the WCA as socio-spatial structure with emergent properties. Emergence, central to critical realist ontology, denotes 'situations in which the conjunction of two [or] more features or aspects [the WCA in our case] gives rise to new phenomena, which have properties which are irreducible to those of their constituents [the individual nodes of the world city network], even though the latter are necessary for their existence' (Sayer 2000, p.12). Consequently, the WCA is a real existing spatial structure with material effects that needs to be critically examined (Jonas, 1994; 2006). Nevertheless, the internal geography of the WCA is stratified, with some spaces being more necessary or strategic to orchestrate spheres of circulation than others (Cox, 2013; Taylor et al. 2014). Contrary to Castells $(1983,1989)$, who considers networks as the fundamental expression of contemporary socio-spatial formations, we consider networks an important social-spatial abstraction (Sayer, 1992 [1984]) to study the WCA. A selection of properties of a spatial object described in the topological language of nodes and dyads is what we mean with the epistemological category 'network'. Hence the network category highlights some aspects of a concrete object while subduing others (cf. Emirbayer, 1997). The consequence is that other possible abstractions of the WCA - i.e. in terms of its Territory, Scale, Place (and Network) (TSPN) properties (Jessop et al. 2008), can provide important complementary perspectives.

In order to make these epistemological considerations bear on world city research we propose the following twofold analytical strategy. First, we deduce socio-spatial properties of the WCA by reading that space through the imbricate abstractions of TSPN. This expansion of our spatial conceptual repertoire allows a better appreciation of the mechanisms that make 
the WCA a structure with emergent properties. Fortunately, debates in human geography in the last four decades have brought forward an impressive conceptual toolkit to analyze the different TSPN abstractions of socio-spatial structures. Less fortunate is that these discussions have often been conducted in a rather 'imperialist' manner where the newest concept was to subordinate or replace its predecessors (Leitner and Miller, 2007). Following Paasi $(2004 ; 2008)$ and diverging from Jessop et al. (2008), we do not treat the four TSPN concepts as mutually exclusive as their overlap enriches, rather than blunts, their analytical power. Second, we inductively build up WCA space by analyzing the socio-spatial practices of APS in Euromarket capital attraction for their clients. By comparing three different cases of the spaces of practice (Watson and Beaverstock, 2014) of Eurobond issuance, we can tentatively assess the relative importance of each of the involved places for the success of the operation. Drawing on Tilly's (1984) encompassing method, the purpose of our Eurobond analysis is to calibrate the usefulness of the analytical apparatus and work towards a first cut on the internal structure of the WCA under financialized globalization. 'Encompassing comparisons begin with a large structure of process [the WCA][...] [Subsequently, you] select locations within the structure or process and explain similarities or differences among those locations as consequences of their relationships to the whole.' (Tilly, 1984: 125). The encompassing method therefore allows us to probe the contingent relations between the world city nodes and the emergence of the archipelago as a socio-spatial object (cf. Sayer, 2000).

\section{Space made: Reading the world city archipelago through TSPN}

The following subsections examine how abstracting through network, place, territory and scale perspectives, discussed in a different order than the TSPN acronym suggests, help understand the production and stratification of the WCA. 


\section{Network}

Much of the progress in understanding geographies of contemporary capitalism has been achieved by abstracting the world in terms of networks (Brown et al., 2010; Coe et al., 2014; Taylor and Derudder, 2015). Castells (2000c: 14) famously describes the workings of the networked space of flows as 'the technological and organizational possibility of organizing the simultaneity of social practices without geographical contiguity'. Reading the WCA as the product of networked processes remains powerful in explaining cooperation and complementarity between the nodes that make up the WCA (Amin and Thrift, 1992). The networks are to an important extent reproduced through the practices of transnational communities working in APS (Jones, 1998; Faulconbridge, 2007). Each world city node contributes, often place-specific, knowledge and practices to the larger whole, as firms link various 'islands of expertise' (Bunnel and Coe, 2001). What makes these assemblages of knowledge stretched over space ultimately useful is the fact that they pertain, whether 'financial' or 'non-financial', to the construction of material circuits of value (Lee, 2006, 2011; Sokol, 2013). In practice, a lot of APS work takes place in project ecologies (Grabher, 2004) that settle down temporarily in world cities. The knowledge produced in these ecologies ultimately allows for translation, it makes a particular economic geography work in the material world (Law and Hetherington, 2000). For instance, knowledge on economic peripheries or emerging markets, produced and conveyed through personal or institutional APS networks often becomes subsumed in financial products (Lai, 2011; Wainwright, 2013).

\section{Place}

Alternatively, the WCA can be understood as outcome of place-making processes. According to Ley (1977), analyzing how humans socially construct place provides insight in the takenfor-granted spatialities of lifeworlds. The concept of place grasps how humans define situations and view, interpret and act upon the world. Pred (1984) expands this notion by showing how places emerge as 'historically contingent processes': taken-for-granted 
properties of place relate to routinized interactions and conventions of groups of people. Gradually, these solidify in consciousness through structuration (Giddens, 1984). This relation between routine, place and identity is also apparent in Massey's work (1994; 2004), although she extends the subject in important ways. For Massey (1994: 168) a sense of place is 'formed out of the particular set of social relations which interact at a particular location' and which are by definition unique to that location. Thus place and its (dominant) meaning is the result of the - often conflictual - negotiation between the presences and absences that exist at that fragment of time-space, exemplifying the intertwinement between places and networks (cf. Pierce et al., 2011).

Massey brings to the fore how places become coded with meaning and how some relations, which are nevertheless necessary for the reproduction of the place, disappear from view in dominant perceptions. This coding consequently has effects on what is considered proper behavior in that context. Allen and Pryke (1994) fittingly show how London is predominantly produced as a 'service space' place. Dominant values of financial capitalism and the City of London get coded into space based on the routinized work practices of those workers associated with 'advanced' service work. The equally necessary, but 'less advanced', cleaners, guards and restaurant workers are literary 'put into place': in the background, as seemingly unnecessary. Similarly, the discourse of financial media such as The Economist, its advertisements, and their invoked spatial imagery of 'global cosmopolitan life' (Taylor, 2001) construct the WCA as an imaginative geography that has material effects. Another example is Kleibert's (2015) analysis how the 'enclave economies' of services offshoring in Manilla, associated with APS back office work, create specific places, where an 'Americanized model of modernity' and consumption gets coded in the built environment. Such coding practices contribute to the discursive hegemony of perceiving dominant spaces of capital accumulation as 'normal', making it a profoundly geopolitical act (Agnew and Corbridge, 1995: 47). 


\section{Territory}

In recent work, Sassen $(2008,2013)$ stresses the crucial importance of territory for global accumulation strategies to work. Territories emerge through a process of institutionalization where eventually boundaries are construed, and through which power is exercised and attempts at - enforcement of social order are conducted (Paasi, 2003). Formal state territoriality is the archetypical example in this respect. The fact that places get instituted through routines and coding already alludes to a notion of territorialization, exemplifying the intertwinement of place and territory. Recent theoretical interventions stress the notion of territory as a political technology based on calculative technologies (Elden, 2005; 2010), where space is bounded and controlled in technical and legal ways. Painter (2010) regards 'territory as an effect' of a successful application of such a political technology. These political technologies change over time so that various historical conjunctures will show other ways of territory than the state forms of territory per se (Agnew and Corbridge, 1995: 5; Elden, 2010). As Sassen (2013) argues, territory can 'deborder' formal state territoriality and emerge autonomously of the state. In this light, financial spaces such as offshore exchange and over-the-counter-markets form a 'bordered space of private financial transactions that is increasingly free from national and international regulatory authorities' (Sassen, 2013: 36). Further, she regards the global network of financial centers as 'constituting the elements of a novel type of multi-sited territory, one that diverges sharply from the territory of the historic nation-state' (Sassen, 2013: 37). Global organizational assemblages (Sassen 2013) such as the WCA are able to crosscut traditional inter-state borders and are endowed with a particular power that is territorial in nature, even if it appears less rigid than formal state territoriality. While the WCA is no 'state space' with clearly demarcated borders in the classical sense, it is a crucial infrastructure - part of the political technology - that makes interterritoriality (Taylor, 1995) possible for global capitalist firms to optimize their profit and taxation strategies. 


\section{Scale}

Fourth and finally, the WCA can be understood as the outcome of a scalar fix (Cox, 2002) for accumulation with connections with varying strength to different urban-, region- and nationcentered accumulation regimes. Scales are neither natural givens, nor mere heuristic tools for the geographer (Marston, 2000) and should not be reduced to interplay between a fuzzily defined 'local' and 'global' (Gibson-Graham, 2002). Neil Smith (2008 [1984]) refers to the structuring role that the capitalist system plays in the 'solidification' (Smith and Dennis, 1987) of spatial scales. According to Smith (2008 [1984]: 181, 229) capital tends to 'produce' scale, but we need to unpack how this production is enacted through the social construction of material circuits of value by (groups of) actors (Lee, 2006; cf. Marston, 2000).

A scalar fix depends on repetition of success in circuits of value and to more-or-less routinized scripts for repeated capital accumulation cycles. Such scripts involve relations between labor, the means of production, land, and knowledge altogether underpinning the tendency of capitalism towards spatial fixity (Harvey, 1985). Since there is a 'fixed' interest in sustaining accumulation in a particular place, we can expect a form of structured coherence to emerge (Harvey, 1985; Cox and Mair, 1991). Local politics, land markets, and constituencies benefit from sustained accumulation in place. Consequently, resonances between the scale of accumulation and the scale of social, economic and political interests are likely to induce, and strengthen, place formation (Kurtz, 2002; building on Benford and Snow, 2000). For example, as a corollary to world city formation, growth coalitions with more localized accumulation strategies can emerge that hinge on the closing of rent gaps through commercial and real estate development (Swyngedouw and Baeten, 2001). A supra-national example is the increased solidity of the European scale that can be attributed to the heightened relevance of that scalar fix to ensure the predictability of accumulation projects related to Europeanization (Brenner, 1998b, Bassens et al., 2013a). As accumulation 
regimes change, the power relations, or scaffolding, between geographical scales also change (Brenner, 1998a), which led to increased prominence of particular global cities (Brenner, 1998b). The politics of establishing the English South East as the growth-pole of the British economy, is a well-documented example of a region being 'scaled' to benefit from the new accumulation regimes, while bypassing other regions in the UK (Allen et al., 1998). The latter examples underline how production of scale is intimately intertwined with the production of place. Neither, however, is reducible to the other.

While inherent in capitalism, financialized globalization has deepened stratification in terms of which individual locales can 'scale' to the most profitable scale of accumulation. Swyngedouw (1997), for instance, shows how the geographical effects of global financial products and derivatives are in fact part of a scale politics of different locally grounded, but politically unequal (groups of actors in) places. Financial products are produced 'in place' and have effects in different places, being testimony of how a scalar abstraction such as 'the global' is the product of cumulative chains of small 'local' events (Storper, 1988; GibsonGraham, 2002). Some financial products are necessarily grounded where the right combinations of legal and material infrastructure and knowledge are available. Moreover, 'opaque' structured finance products are only accessible, comprehendible, or marketable in particular places like the City of London. Other 'plain vanilla' investment products like stocks and bonds seemed, at least until the financial crisis, much more translucent or transparent (Clark and O'Connor, 1997). Opaque products, however, have become an indispensable tool for governments and companies alike to manage their economic operations under financialized globalization (Lee et al., 2009; Pike and Pollard, 2010; Pani and Holman, 2013). This opaqueness is a crucial mechanism in turning the WCA and its APS operators into an obligatory passage point - a necessary space- for global capitalism. This ultimately strengthens the ability to extract fees by actors in key WCA nodes. 
The deepening stratification under financialized globalization requires further appreciation of the difference between necessary and contingent spaces for capitalist accumulation (Cox, 2013), which can be empirically assessed through differentiation between 'spaces of dependence' and 'spaces of engagement' (Cox, 1998a). A space of dependence focuses on those socio-spatial relations that are non-substitutable for a particular accumulation routine (Cox and Mair, 1988). 'Dependency space' can be a single community or city, but this is not necessarily so. Other scales, including non-contiguous ones such as parts of a network, or a commodity chain could equally qualify (Cox, 1998b). A space of engagement is a space 'where the politics of securing a space of dependence unfolds' (Cox, 1998a: 2). This can be interpreted 'defensively' to protect vested capitalist interests, but also 'offensively' - geared towards capitalist expansion. Creating new circuits of value is a clear example of engagement to enable accumulation. Arguably, a lot of the new nodes in the expanding WCA are there for exactly that reason: a basing point for capitalist firms in a new context to engage new labor relations, find new markets or optimize profits (Friedmann, 1986). If such an engagement is successful and routinized circuits of value are established, the place gradually becomes less substitutable and the position in the network becomes more important for the practices in the WCA as a whole (cf. Cox, 1998a; 2013). Thus, the relation between spaces of dependence and spaces of engagement is a continuous one. The more we move towards the dependence pole the higher the degree of (sunk) switching costs to relieve that dependency.

\section{Make space: Analyzing socio-spatial practices of APS under financialized globalization}

Having theorized the spatial properties of the WCA through TSPN deductively, we now probe that spatiality inductively from the practices of APS firms. We examine Euromarkets, where 
capital is attracted via international onshore and offshore financial centers outside domestic security regulations (Roberts, 1995; Burn, 1999). Euromarkets have developed since the 1950s, mainly as a way of circumventing territorially-enforced restrictions on capital flows under the Bretton Woods system (Thrift and Leyshon, 1988; Palan et al., 2010). The Eurobond market ${ }^{6}$ in particular is regarded by Taylor et al. $(2013,501$; cf. Burn, 1999) as 'a true pioneer of contemporary globalization'. Eurobond markets currently amount to US\$27 trillion of debt outstanding, approximately a third of the US $\$ 75$ trillion debt outstanding in onshore domestic bond markets (BIS, 2011). Eurobonds are popular with issuers as a way of hedging currency risk, accessing a broader investor base, and to decrease the borrowing cost via off-balance sheet securitization structures. For investors, often of the institutional kind, Eurobonds offer much sought-after high yields and portfolio diversification (Claes et al., 2002). Because of the involvement of institutional investors like pension funds, which can only invest in assets listed on stock exchanges, many securities are registered on major stock markets. Much of the trading, however, occurs Over The Counter (OTC): directly between market participants. This makes trading in these markets opaque, a situation which is aggravated by the fact that most securities are 'bearer bonds' that require no registration of ownership so that holdings and the associated capital gains remain anonymous and escape withholding tax in the country of residence (Choudry, 2008).

We map the socio-spatial practices of Eurobond issuance by a content analysis of issuance prospectuses. These are a mandatory medium for publicly listed securities that discloses their legal and geographical structure and the actors involved. The method has previously been applied to understand the entanglements of Islamic and 'conventional' finance (Bassens et al., 2013b). We complement that analysis of the Emaar Sukuk (Figure 1), which

\footnotetext{
${ }^{6}$ Eurobond markets are a specific submarket of Euromarkets, which also include offshore finance and trading of Eurocurrencies. In this paper we use the term Eurobonds to refer to variety of Eurodebt products, ranging from Islamic bonds (sukuk), mortgage-backed securities, and other types of investment notes.
} 
is a finance scheme for Dubai's government-related property development firm, with two cases in conventional markets: an issue of $€ 737$ million commercial real-estate mortgage backed (CMBS) securities by a German property developer ('German Residential CMBS', see Figure 2) and an issue of $£ 500$ million Euronotes by the government-related Russian fossil fuel company Gazprom ('Gazprom Loan Participation Notes', see Figure 3) ${ }^{7}$. These three cases of Eurodebt - an Islamic bond, CMBS, and Euronotes - illustrate how APS in world cities produce entanglements with global financial markets during the issuance of securities. This is evident for corporate and state institutions alike both in 'developed' and 'emerging' economies.

---- Insert figures 1-3 about here----

Figures 1-3 detail the actors and spaces involved in the structuring, management, investment, and legal advising of international debt structures. While there are differences in who is involved, all cases exhibit a strong dependence of corporate and government-related institutions on a variety of fee-based APS services providers such as investment banking, law firms, accountancy and auditing firms, consultancy firms, rating agencies, and trust companies. The basic mechanism to tap into Euromarkets is to contact an investment bank that structures the debt with the help of law firms, underwrites the securities, and places them with (institutional) clients. In most cases, the actual issuance occurs not by the client firm itself, but by a purely legal entity - either a holding company or a Special Purpose Vehicle (SVP)- to minimize withholding tax for investors. Eventually the securities are rated and listed on international exchanges. At that stage trust companies perform a number of

\footnotetext{
${ }^{7}$ Emaar Sukuk were registered at the London Stock Exchange on February $3^{\text {rd }}, 2011$. German Residential CMBS and Gazprom Euronotes were registered on the Irish Stock Exchange, resp. on 4 October 2013 and 26 September, 2013. Prospectuses can be retrieved online at www.londonstockexchange.com and www.ise.ie
} 
roles as trustee, custodians, fiscal agents or listing agents of the securities. Actual payment flows are cleared by specialist providers such as Clearstream or Euroclear.

In the context of Euromarkets, the APS firms are obligatory passage points to 'unlock' specific archipelago-like offshore structures for their clients. Triangulating the three cases allows for an inductive determination of stratification within the WCA. A first observation is London's omnipresence in all issuances, without which the structure would cease to function. Many of the socio-spatial practices occur within the bounds of the City itself in part because of its meso-corporatist territorial stature (Thrift and Leyshon, 1994: 313 cf. Burn, 1999: 251). Investment banks, backed up by a range of law firms, act as structuring agents and (lead) managers and thus hold the expertise that enables the deal. This dependence stems from the fact that the combination of London-based firms hold the expertise to open-up offshore spaces via SPVs to their clients; access which comes at the cost of steep consultancy fees. Echoing Amin and Thrift (1992), the world-cityness of London emerges from the nodal agglomeration of activities, but also from the ability to rapidly and successfully access other spaces in a networked way.

Much of the dependence of clients on London-based actors draws on the capability of APS firms to allow clients to reach out to spaces outside the archipelago (i.e. spaces of engagement) to enter offshore markets. Here, Dubai, Hanover, and Moscow respectively are necessary localities for their particular issuance, but less likely to be relevant for other issuances. In the German CMBS case, we note that legal advice to the issuance managers, which is absent in Hanover, is brought in from Frankfurt via a number of law firms. This points to the networked nature of how relevant knowledge for a particular issuance is assembled. Frankfurt may not be an obligatory passage point for the Emaar Sukuk, but the issuance of the German CMBS would probably be less successful without the built-up knowledge of Frankfurt-based law firms. This confirms a 'world city division of labor' between 
London and Frankfurt to complete the deal (cf. Faulconbridge, 2004). For the Gazprom structure, Moscow is acting as the gateway to the Russian market and the space of engagement with official state entities.

Third, engagements with offshore jurisdictions (i.e. intermediary spaces) is a constant as Euromarkets depend on legal structures that allow capital to be (re)routed offshore. The Cayman Islands are a well-known example, but also Ireland, the Netherlands, Luxembourg, and London itself act as offshore-enabling jurisdictions. The attractiveness of these spaces is territorial as well as networked in nature: within these jurisdictions light-touch regulation allows low-cost and rapid incorporation of SPVs as 'societés anonymes' in Luxembourg or 'stichtingen' in the Netherlands. Ireland is where securities are registered through listing on the Irish Stock Exchange. This allows investors to avoid taxation on the income received on the notes, but activities in these jurisdictions are usually limited to the listing process or trustee services (cf. Wainwright, 2011). Offshore jurisdictions seem generic in nature, as apparently others can easily replace them. In practice, however, stability in offshore routines is the norm: specificities of juridical knowledge and predictability of a place due to shared (colonial) pasts (Wójcik, 2013a: 337; Haberly and Wójcik, 2015) incite preference for established relations. Moreover, each of these jurisdictions generate specific regulatory and tax-evading opportunities suggesting an 'offshore division of labor' that allows regulatory arbitrage if combined. Constructing circuits that combine the opportunities of various jurisdictions is again dependent on expertise which is often hired in the City.

\section{Qualifying APS practices in Euromarkets through TSPN}

We continue by interpreting the Eurobond issuances through the TSPN perspectives to elucidate complementary perspectives (see Table 1). 


\section{--- Insert Table 1 about here ---}

A 'classic' network reading on these Eurobond cases reveals the multi-sitedness and the cooperation in the work executed by the project ecologies involved in the structuring of the Eurobond. From the network perspective, generating fee-based business in Frankfurt, Dubai, or Moscow translates in a commensurate amount of work in London. Yet, besides networkbased cooperation, the Euromarkets also highlight stratification and hierarchy within the WCA. Eurobond issuance appears to depend on a hierarchical continuum ranging from necessary places (i.e. London) to contingent places (i.e. the places of origination), with offshore territorial jurisdictions as an intermediate category. As if it were mercury, international capital flows have a tendency to 'stick to' and 'pool' in certain places (Clark, 2005). Even in deregulated global (financial) markets, it appears capital cannot flow everywhere: tax havens are out there as a seemingly generic category, but operational requirements (e.g., buying coffee, offshoring profits, attracting finance) will require specialized services restricted to a limited choice of jurisdictions. Moreover, access to these jurisdictions is very likely not a matter of choice, but is 'fixed' by specialized APS in leading world cities.

For Eurobonds to 'work' they clearly need the formal state territorialities as they pertain to financial transactions. Accumulation strategies advised by APS firms rely on existing or new state spaces (Brenner, 2004), that draw on institutionalization of space and boundary formation: the skillful combination of different political-juridical technologies by APS to engage in 'tax planning' (Palan et al., 2010; Wójcik, 2013a). Offshore jurisdictions, either as enclaves governed by international (common) law (e.g., Dubai International Financial Centre) or by a 'competitive' national regulatory system (e.g., The Netherlands, Luxembourg) are emblematic in this regard. Capitalist firms rely on a territory-as-effect that is accessible against a fee paid to APS intermediaries - through the knowledge available in the WCA. The 
informal territoriality of Eurobond markets is to some extent formalized by the use of common law as a governing mechanism in nearly all transactions (Palan et al., 2010). This implies work in the spaces of origination, especially for teams of domestic and foreign law firms, as national legal systems have to speak to common law-based contracts. This provides leeway for APS to engage in institutional entrepreneurship and change the territorial features of jurisdictions (Faulconbridge and Muzio, 2014).

In contrast to state territory imbued with 'stateistics' (Taylor, 2013), informal territories like the WCA generally lack publicly available calculative technologies to map what goes on in that space, making the project of unveiling the socio-spatial practices that constitute it all the more necessary. This also highlights the relevance of place-making processes. In much world city discourse, the WCA is represented as a space for accumulation in itself: a seductive set of interconnected knowledge-intensive urban economies. Hence, 'world city places' tend to be discursively coded as aspirational rather than critical geographies (Bunnell, 2013). Reviewing the Starbucks vignette and the triangulation of Eurobond cases, it is clear that these aspirational tales of world cities as place do not expose the geographies of tax evasion and/or offshore finance that are part and parcel of financialized globalization in which world cities are deeply implicated (but see Beaverstock et al., 2013; Wójcik, 2013a; Haberly \& Wójcik, 2015).

Drawing on debates on scale, it follows that when connections to the WCA are established, the newly incorporated spaces of engagement receive properties of the WCA scale that serve to normalize, legitimize, and reproduce accumulation according to WCA practices. New 'islands' emerge as new sites for investment are identified by applied economic geography conducted in the APS complex (Lee, 2002). Following the identification of possibilities for capital accumulation, APS presence is established and these places become spaces of dependence holding an expertise relevant for future practice. In our case, the 
expertise gained during the issuance of a Eurobond in a particular national or niche market may be the feedstock for future deals taking place in the wider region. This is most obvious for Dubai: drawing on its networks with investment banks operating from London, this city is becoming a regional center for expertise on the structuring of Islamic bonds (Bassens, 2013). Moreover, as illustrated by the Gazprom and Emaar cases, government-related enterprises actively utilize WCA space, while more generally pension funds in European states or sovereign wealth funds in many emerging economies are among the prime investors in international financial markets (Clark, 2003; Dixon and Monk, 2012). Engagements with the WCA may hence incentivize aspirational world city-formation policies as an accumulation strategy in itself through its effects on urban real estate and labor markets. Servicing a niche within the global financial system, as is the case in Luxembourg, can become important for the reproduction of that particular national political economy (Dörry, 2014). National territories get a stake at being part of the WCA, and their respective governments become susceptible to lobbying by the APS complex. However, to what extent such dynamics 'solidify' as a new scale for accumulation strongly depends how elites pick-up and promote this particular function of place and deem it relevant as growth strategy. This is as much a process of veiling other less glamorous growth strategies, for instance those depending on cheap immigrant labour in construction that very much supports Dubai's material emergence. In Dubai, the political desire to develop the as a regional financial centre synchronized perfectly with the ambitions of London-based banks to socially construct new circuits of value in the Gulf Region (Bassens, 2013).

\section{Concluding remarks}

In his critical appraisal of the evolution of Manuel Castells work, Stalder (2006: 202-203) remarks that 'the theory of the space of flows [...] will be among the most enduring contributions of the theory of the network society to our understanding of the new historical 
period.' Yet, our analysis shows that this 'network-centrism' (Jessop et al. 2008) makes world city research susceptible to the critique of legitimizing the very imperatives of neoliberal globalization (Massey, 2007). Moving beyond the commonsensical assertion that the state still matters in globalization, critical geography urges us not only to identify false beliefs operating in the world, but also make it comprehendible why these beliefs are held (Sayer, 2009). How can we understand the, by now, equally hegemonic image of a networked borderless world, while place and territory clearly still matter? This networked geopolitical order (Agnew and Corbridge, 1995) that the WCA constitutes and represents, we argue, is the result of a politics of scale requiring ongoing social and material construction. We have therefore made the case that, to retain world city research's critical edge regarding the role of the WCA in financialized capitalism, we need to understand the WCA through a plurality of socio-spatial abstractions that, apart from networks, includes complementary place-, territory, and scale-making.

This brings back into focus the politics of how socio-spatial structures solidify from day-today-practices undertaken to reproduce and expand capitalism. Although accumulation hinges on networking places and territories at the firm level, this does not imply WCA space is isotropic in terms of power at the structural level: a diversity of contexts can be 'plugged into' the network of globalized financial capitalism, but not all places are and can be plugged into the network on equal terms: positionality (Sheppard, 2002) matters. In contrast to what a network view discloses, the WCA consists of a 'core' of spaces of dependence and a 'periphery' of 'spaces of engagement'. Some practices are 'amplified' while other possible worlds are 'subdued', which illustrates the importance of place making in the nodes of the WCA. The WCA integrates the contexts implied in places, territories and scales into global networks, but it does so in unequal and variegated ways (cf. Brenner et al., 2009). Moreover, these two poles in fact form a continuum that allows for semi-peripheral developmental processes such as world city and emerging market formation. The competition to be the 
preferred offshore tax haven in a given geographical or market area is another case in point (Wainwright 2013; Haberly and Wójcik 2014).

Our empirical excavation of what is currently going on in and beyond WCA space is still a preamble to what could be a broader analysis of the socio-spatial practices emanating from world cities under financialized globalization. This paper has zoomed in on particular geographies of capital attraction in Euromarkets that emphasize the financial aspects of the WCA. Further research could entail a more systematic analysis of capital attraction structures in emerging or developed markets. Moreover, the socio-spatial practices at the other moments of capital deserve our undivided attention. In particular: how is WCA space implicated when firms offshore their profits? Which APS firms organize such practices of regulatory arbitrage? But also more generally, we need to know more about the geographies of consultancy by the APS complex to financialized firms as they devise global accumulation strategies. For example, to what extent do financial optimization motifs ultimately feed back into sunk investment decisions in means of production and labor? Beyond these practices themselves, it is paramount to analyze processes of legitimization and normalization across various spatial scales, by which they are allowed to continue as seemingly benign 'postindustrial' growth strategies. Unveiling the place-, territory- and scale-making of financialized accumulation thus seems a project that stretches beyond the means of critical urban studies itself, and includes a societal critique of the dominant accumulation regime.

In any case, as corporate control and state finance is increasingly subject to market discipline, the WCA and the 'economically necessary' functions it is deemed to fulfill at various spatial scales have become a space difficult to bypass if competitive accumulation is the desired outcome. Just as the 'global' economy was initially a space emerging from the strategies of industrial capital to maintain accumulation (Friedmann, 1986), the continuous engagement with offshore spaces through world cities has become a necessary ingredient to 
sustain accumulation in the current age. Local structured coherence and place-based policies meanwhile reinforce the naturalization of the WCA as the relevant scale of capital accumulation. The WCA thereby unfolds as a crucial element in the contemporary geopolitical order and its routinized rules, institutions, activities and strategies through which the international political-economy operates and on which states depend (Agnew and Corbridge, 1995: p.15). For now, we propose to understand the WCA as the contemporary footprint of the core of the capitalist world-economy under conditions of financialized globalization. This core exhibits internal stratification and hierarchy, as well as a division of labor between nodes toward the whole (cf. Arrighi and Drangel, 1986), which we can assess through the TSPN approach. Moreover, the WCA reaches out to external arenas and incorporates them in financial circuits of value, expanding the WCA's footprint. The structuring and management fees - the core activities - are subsequently repatriated. To merely regard such incorporation in terms of 'globalization', 'modernity', or 'development' instead of 'peripheralization' and 'dependency' is a debate to be urgently rejuvenated.

\section{References}

Agnew, J. A. and S. Corbridge (1995) Mastering space: hegemony, territory and international political economy. Routledge, London and New York.

Allen, J. (2010) Powerful city networks: more than connections, less than domination and control. Urban Studies 47.13, 2895-2911.

Allen, J. and M. Pryke (1994) The production of service space. Environment and Planning D: Society and Space 12.4, 453-475.

Allen, J., D. Massey and A. Cochrane (1998) Rethinking the region. Routledge, London and New York.

Amin, A. and N.J. Thrift (1992) Neo-Marshallian nodes in global networks. International Journal of Urban and Regional Research 16.4, 571-587.

Arrighi, G. and J Drangel (1986) The Stratification of the world-economy: An exploration of the semiperipheral zone. Review (Fernand Braudel Center), 10.1, 9-74.

Bank for International Settlements (2011) BIS quarterly review March 2011 [WWW document]. URL http://www.bis/org (accessed 12 March 2014).

Bassens, D. (2013) The economic and financial dimensions. In M. Acuto and W. Steele W (eds.), Global city challenges: debating a concept, improving the practice, Palgrave 
Macmillan, Houndmills and New York.

Bassens, D., M. van Meeteren, B Derudder and F. Witlox (2013a). No more credit to Europe? Cross-border bank lending, financial integration, and the rebirth of the national scale as a credit scorecard. Environment and Planning A 45.10, 2399-2419.

Bassens, D., E. Engelen, B. Derudder and F. Witlox (2013b) Securitization across borders: organizational mimicry in Islamic finance. Journal of Economic Geography 13.1, 85-106.

Bassens, D. and M. van Meeteren (2014) World cities under conditions of financialized globalization: Towards an augmented world city hypothesis. Progress in Human Geography. DOI: $10.1177 / 0309132514558441$

Beaverstock, J. V., R.G. Smith and P. J. Taylor (2000) World city network: A new metageography? Annals of the Association of American Geographers 90.1, 123-134.

Beaverstock, J. V., S. Hall and T. Wainwright (2013) Servicing the super-rich: new financial elites and the rise of the private wealth management retail ecology. Regional Studies 47.6, 834-849.

Benford, R. and D.A. Snow (2000) Framing processes and social movements: an overview and assessment. Annual Review of Sociology 26, 611-639.

Braudel, F. (1984) The perspective of the world. William Collins Sons \& Co, London.

Brenner, N. (1998a) Between fixity and motion: accumulation, territorial organization and the historical geography of spatial scales. Environment and Planning D: Society and Space 16.4, 459-482.

Brenner N. (1998b) Global cities, glocal states: global city formation and state territorial restructuring in contemporary Europe. Review of International Political Economy 5.1, 1-37.

Brenner, N. (2004) New state spaces. Oxford University Press, Oxford.

Brenner N, J. Peck and N. Theodore (2009) Variegated neoliberalization: geographies, modalities, pathways. Global Networks 10.2, 1470-1470.

Brown, E., B. Derudder, C. Parnreiter, W. Pelupessy, P.J. Taylor and F. Witlox (2010) World city networks and global commodity chains: toward a world-systems' integration. Global Networks 10.1, 12-34.

Bunnell T, (2013) Antecedent cities and inter-referencing effects: learning from and extending beyond critiques of neoliberalisation" Urban Studies DOI. 0042098013505882.

Bunnell, T. and N.M. Coe (2001) Spaces and scales of innovation. Progress in Human Geography 25.4, 569-587.

Burn, G. (1999) The state, the City and the Euromarkets. Review of International Political Economy 6.2, 225-261.

Castells, M. (1983) Crisis, planning, and the quality of life: managing the new historical relationships between space and society. Environment and Planning D: Society and Space 1.1., 3-22. 
Castells, M. (1989) The Informational City. Oxford: Blackwell.

Castells, M (2000a) The Rise of the Network Society, 2nd edition. Ofxord: Blackwell

Castells, M (2000b) End of Millennium, 2nd edition. Oxford: Blackwell.

Castells, M. (2000c) Materials for an exploratory theory of the network society. The British Journal of Sociology 51.1, 5-24.

Castells, M. (2000d) Toward a sociology of the network society. Contemporary Sociology 29.5, 693-699.

Castells, M. (2001) Informationalism and the network society. Epilogue to Pekka Himanen, The hacker ethic and the spirit of informationalism., Random House, New York, 155-178.

Choudry, M. (2008) The Eurobond Market. In F.J. Fabozzi (ed.), International Handbook of Finance, Vol.1 Financial Markets and Instruments. Wiley, Hoboken NJ, 271-283.

Christophers, B. (2009) Complexity, finance, and progress in human geography. Progress in Human Geography 33.6, 807-824.

Clark, G.L. (2002) London in the European financial services industry: locational advantage and product complementarities. Journal of Economic Geography 2.4, 433-453.

Clark, G.L. (2003) Pension security in the global economy: markets and national institutions in the 21st century. Environment and Planning A 35.8, 1339-1356.

Clark, G.L. (2005) Money flows like mercury: the geography of global finance. Geografiska Annaler B 87.2, 99-112.

Clark, G.L. and K. O'Connor (1997) The informational content of financial products and the spatial structure of the global finance industry. In K.R. Cox (ed.), Spaces of globalization: reasserting the power of the local, The Guilford Press, New York.

Claes, A.G.P, R. Polfliet and M.K. De Ceuster (2002) Anatomy of the eurobond market 19802000. European Financial Management 8.3, 373-386.

Coe, N.M., K.P.Y. Lai, and D. Wojcik (2014) Integrating Finance into Global Production Networks. Regional Studies 48.5, 761-777.

Cox, K.R. (1998a) Spaces of dependence, spaces of engagement and the politics of scale, or: looking for local politics. Political Geography 17.1, 1-23.

Cox, K.R. (1998b) Representation and power in the politics of scale. Political Geography $17.1,41-44$.

Cox, K.R. (2002) "Globalization", the "regulation approach," and the politics of scale. In A. Herod and M.W. Wright (eds.), Geographies of Power, Placing Scale). Blackwell Publishing, Malden.

Cox, K.R. (2013) Territory, scale, and why capitalism matters. Territory, Politics, Governance $1.1,46-61$.

Cox, K.R. and A. Mair (1988) Locality and community in the politics of local economic 
development. Annals of the Association of American Geographers 78.2, 307-325.

Cox, K.R. and A. Mair (1991) From localised social structures to localities as agents. Environment and planning A 23.2, 197-213.

Derudder, B., M. Hoyler, P.J. Taylor and F. Witlox (eds.) (2012) The International Handbook of Globalization and World Cities. Edward Elgar, Cheltenham.

Dixon, A.D. and A.H. Monk (2012) Rethinking the sovereign in sovereign wealth funds Transactions of the Institute of British Geographers 37.1, 104-117.

Dörry, S. (2014) Strategic nodes in investment fund global production networks: the example of the financial centre Luxembourg. Journal of Economic Geography. DOI:10.1093/jeg/lbu031

Elden, S. (2005) Missing the point: globalization, deterritorialization and the space of the world. Transactions of the Institute of British Geographers 30.1, 8-19.

Elden, S. (2010) Land, terrain, territory. Progress in Human Geography 34.6, 799-815.

Emirbayer, M. (1997) Manifesto for a relational sociology. The American Journal of Sociology 103.2, 281-317.

Faulconbridge J.R. (2004) London and Frankfurt in Europe's evolving financial centre network. Area 36.3, 235-244.

Faulconbridge, J.R. (2007) Relational networks of knowledge production in transnational law firms. Geoforum 38.5 , 925-940.

Faulconbridge, J. R. and D. Muzio (2014) Transnational corporations shaping institutional change: the case of English law firms in Germany. Journal of Economic Geography. DOI:10.1093/jeg/lbu038

Frank, A.G. (1966) The development of underdevelopment. Monthly Review 18.4, 17-30.

Friedmann, J. (1986) The world city hypothesis. Development and Change 17.1, 69-83.

Friedmann, J. (2000) Reading Castells: Zeitdiagnose and social theory. Environment and Planning D: Society and Space 18.1, 111-120.

Froud, J., Johal, S., Leaver, A., and Williams, K. (2006) Financialization and Strategy: Narrative and Numbers, Routledge: Abingdon/New York.

Financial Times (2014) Scandals fail to dent accountancy's big four in 2014 in UK. Accessed online, 15/06/2015, from http://www.ft.com/

Gerring J, (2007) Case Study Research: Principles and Practices. Cambridge University Press, Cambridge UK.

Gibson-Graham, J. K. (2002) Beyond global vs. local: economic politics outside the binary frame. In A. Herod and M. W. Wright (eds.), Geographies of power. Placing scale, Blackwell Publishing, Malden.

Giddens, A. (1984)_ The Constitution of Society. Polity Press: Cambridge. 
Grabher, G. (2004) Learning in projects, remembering in networks? Communality, sociality, and connectivity in project ecologies. European Urban and Regional Studies 11.2, 103-123.

Graham, S. and Marvin, S. (2001) Splintering Urbanism. Networked Infrastructures, Technological Mobilities and the Urban Condition. Routledge, London and New York.

Haberly, D. and D. Wójcik (2015) Tax havens and the production of offshore FDI: an empirical analysis. Journal of Economic Geography 15.1, 75-101.

Harvey, D. (1985) The urbanization of capital Basil Blackwell, Oxford.

Jessop, B. (2003). Informational capitalism and empire: The postmarxist celebration of US hegemony in a new world order. Studies in Political Economy 71/72, 39-58.

Jessop, B., N. Brenner and M. Jones (2008) Theorizing sociospatial relations. Environment and Planning D: Society and Space 26.3, 389-401.

Jonas, A.E.G (1994) The scale politics of spatiality. Environment and Planning D: Society and Space 12.3, 257-264.

Jonas, A.E.G (2006) Pro scale: further reflections on the "scale debate" in human geography. Transactions of the Institute of British Geographers 31.3, 399-406.

Jones, A. (1998) Re-theorising the core: a "globalized" business elite in Santiago, Chile. Political Geography 17.3, 295-318.

Kleibert, J. M. (2015) Islands of globalisation: offshore services and the changing spatial divisions of labour. Environment and Planning A 47, 884-902.

Kurtz, H.E. (2002) The politics of environmental justice as the politics of scale: St James Parish, Louisiana, and the Shintech Sting controversy. In A. Herod and M.W. Wright (eds.) Geographies of power, placing scale, Blackwell, Malden.

Lai, K.P.Y (2011) Marketization through contestation: reconfiguring China's financial markets through knowledge networks. Journal of Economic Geography 11.1, 87-117.

Law, J. and K. Hetherington (2000) Materialities, spatialities, globalities. In J.R. Bryson, P.W. Daniels and J. Pollard (eds.), Knowledge, space, economy, Routledge, London and New York.

Lee, R. (2002) Nice maps, shame about the theory. Progress in Human Geography 26.3, 333-355.

Lee, R. (2006) The ordinary economy: tangled up in values and geography. Transactions of the Institute of British Geographers 31.4, 413-432.

Lee, R. (2011) Spaces of hegemony? Circuits of value, finance capital and places of financial knowledge. In J. Agnew and D.N. Livingstone (eds.), The SAGE handbook of Geographical Knowledge Sage, London, Thousand Oaks and New Delhi.

Lee, R., G.L. Clark, J. Pollard and A. Leyshon (2009) The remit of financial geographybefore and after the crisis. Journal of Economic Geography 9.5, 723-747. 
Leitner, $\mathrm{H}$ and B. Miller (2007) Scale and the limitations of ontological debate: a commentary on Marston, Jones and Woodward. Transactions of the Institute of British Geographers 32.2, $116-125$.

Ley, D. (1977) Social geography and the taken-for-granted world. Transactions of the Institute of British Geographers 2.4, 498-512.

Marcuse, P. (2002) Depoliticizing globalization: From Neo-Marxism to the network society of Manuel Castells. In J. Eade and C. Mele (eds.) Understanding the city : Contemporary and future perspectives. Oxford: Blackwell.

Marston, S.A. (2000) The social construction of scale. Progress in Human Geography 24.2, 219-242.

Massey, D. (1994) Space, place and gender. University of Minnesota Press, Minneapolis.

Massey, D (2004) Geographies of responsibility. Geografiska Annaler B 86.1, 5-18.

Massey, D. (2007) World city. Polity Press, Cambridge UK.

Paasi, A. (2003) Territory. In J. Agnew, K. Mitchell and G. Ó Tuathail (eds.) A companion to political geography. Blackwell, Oxford.

Paasi, A. (2004) Place and region: looking through the prism of scale. Progress in Human Geography 28.4, 536-546.

Paasi, A. (2008) Is the world more complex than our theories of it? TPSN and the perpetual challenge of conceptualization. Environment and Planning D: Society and Space 26.3, 405410.

Painter, J. (2010) Rethinking territory. Antipode 42.5, 1090-1118.

Palan, R., Murphy, R. and Chavagneux, C. (2010) Tax Havens: How Globalization Really Works. Cornell University Press, Ithaca.

Pani, E. and N. Holman (2014) A fetish and fiction of finance: unraveling the subprime crisis. Economic Geography 90.2, 213-235.

Parnreiter, C. (2010) Global cities in global commodity chains: Exploring the role of Mexico City in the geography of global economic governance. Global Networks 10.1, 35-53.

Parnreiter, C. (2014) Network or hierarchical relations? A plea for redirecting attention to the control functions of global cities. Tijdschrift Voor Economische en Sociale Geografie, 105.4, 398-411.

Pierce, J., D.G. Martin and J.T. Murphy (2011) Relational place-making: the networked politics of place. Transactions of the Institute of British Geographers 36.1, 54-70.

Pike A and J. Pollard (2010) Economic geographies of financialization. Economic Geography 86.1, 29-51.

Pred, A.R. (1984) Place as historically contingent process: structuration and the timegeography of becoming places. Annals of the Association of American Geographers 74 .2, 279-297. 
Roberts, S.M. (1995) Small place, big money: the Cayman Islands and the international financial system. Economic Geography 71.3, 237-256.

Sassen, S. (2008) Territory, authority, rights. Princeton University Press, Princeton.

Sassen, S. (2013) When territory deborders territoriality. Territory, Politics, Governance 1.1, 21-45.

Sayer, A. (1992) [1984] Method in social science, a realist approach. Routledge, London and New York.

Sayer, A. (2000) Realism and social science. London, Thousand, Oaks, New Delhi and Singapore: Sage.

Sayer, A. (2009) Who's afraid of critical social science? Current Sociology 57.6, 767-786.

Sheppard, E. (2002) The spaces and times of globalization: place, scale, networks, and positionality. Economic Geography 78.3, 307-330.

Smith, N. (2008) [1984] Uneven development: nature, capital and the production of space. Verso, London and New York.

Smith, N. and W. Dennis (1987) The restructuring of geographical scale: coalescence and fragmentation of the northern core region. Economic Geography 63.2, 160-182.

Sokol, M. (2013) Towards a "newer" economic geography? Injecting finance and financialisation into economic geographies. Cambridge Journal of Regions, Economy and Society $6.3,501-515$.

Stalder, F. (2006) Key Contemporary thinkers: Manuel Castells. Cambridge: Polity Press.

Storper, M. (1988) Big structures, small events, and large processes in economic geography. Environment and Planning A 20.2, 165-185.

Swyngedouw, E.A. (1997) Neither global nor local: "glocalization" and the politics of scale. In K.R. Cox (ed.), Spaces of globalization: reasserting the power of the local, The Guilford Press, New York and London.

Swyngedouw, E.A. and G. Baeten (2001) Scaling the city: the political economy of 'glocal' development-Brussels' Conundrum. European Planning Studies 9.7, 827-849.

Taylor, P.J. (1995) Beyond containers: internationality, interstateness, interterritoriality. Progress in Human Geography 19.1, 1-15.

Taylor, P.J. (2001) Being economical with the geography. Environment and planning A 33.6 , 949-954.

Taylor, P.J. (2004) World city network: a global urban analysis. 1st edition. Routledge, London.

Taylor, P.J. (2013) Extraordinary Cities. Millennia of Moral Syndromes, World-Systems and City/State Relations. Edward Elgar, Cheltenham. 
Taylor, P. J., N. Pengfei, B. Derudder, M. Hoyler, J. Huang, F. Witlox (eds.) (2010) Global urban analysis: A survey of cities in globalization, Routledge, London and New York.

Taylor, P.J., B. Derudder, M. Hoyler and P. Ni (2013) New regional geographies of the world as practised by leading advanced producer service firms in 2010. Transactions of the Institute of British Geographers 38.3, 497-511.

Taylor, P.J., B. Derudder, J. Faulconbridge, M. Hoyler and P. Ni (2014) Advanced producer service firms as strategic networks, global cities as strategic places. Economic Geography 90.3, 267-291.

Taylor, P.J. and Derudder, B., (2015) World city network: a global urban analysis. 2nd edition. Routledge, London.

Thrift, N. J. and A. Leyshon (1988) "The gambling propensity": Banks, developing country debt exposures and the new international financial system. Geoforum 19.1, 55-69.

Thrift, N.J. and A. Leyshon (1994) A phantom state? The de-traditionalization of money, the international financial system and international financial centres. Political Geography 13.4, 299-327.

Tilly, C. (1984) Big Structures, Large Processes, Huge Comparisons. Russel Sage Foundation, New York.

Veltz, P. (1996) Mondialisation, villes et territoires. Presses Universitaires de France, Paris

Wainwright, T. (2011) Tax doesn't have to be taxing: London's "onshore" finance industry and the fiscal spaces of a global crisis. Environment and Planning A 43.6, 1287-1304.

Wainwright, T. (2013) Finance's outsiders? Networks, knowledge and power beyond the City. Journal of Economic Geography 13.6, 1041-1058.

Watson, A. and J.V Beaverstock (2014) World city network research at a theoretical impasse: on the need to re-establish qualitative approaches to understanding agency in world city networks. Tijdschrift Voor Economische en Sociale Geografie 105.4, 412-426.

Wójcik, D (2013a) Where governance fails: advanced business services and the offshore world. Progress in Human Geography 37.3, 330-347.

Wójcik, D. (2013b) The dark side of NY-LON: financial centres and the global financial crisis. Urban Studies 50.13, 2736-2752. 
Table 1 Reading the World City Archipelago through TSPN

\begin{tabular}{|l|l|}
\hline & World City Archipelago \\
\hline Network & $\begin{array}{l}\text { - Complementarity among world cities in global APS office networks } \\
\text { - Multisite knowledge production in APS project ecologies } \\
\text { - World cities as neo-Marshallian nodes in global networks (Amin and Thrift, } \\
1992)\end{array}$ \\
\hline Place & $\begin{array}{l}\text { - Socio-spatial routinization of interactions and conventions in APS lifeworlds } \\
\text { - Selective sense of place formation: coding world cities as advanced service } \\
\text { spaces } \\
\text { - Normalization through partial representation to enable spaces for (financialized) } \\
\text { accumulation } \\
\text { - Places as commodified spaces: 'emerging markets', urban entrepreneurialism }\end{array}$ \\
\hline Territory & $\begin{array}{l}\text { Formal institutionalization of space and boundary formation: offshore centers and } \\
\text { - Informal territorialization: territorialization-as-effect of assembling and } \\
\text { recombining formal territorial capacities (e.g. national jurisdictions) }\end{array}$ \\
\hline Scale & $\begin{array}{l}\text { - Solidification of material circuits of value socially constructed by APS } \\
\text { - Structured coherence, growth coalitions, and fixed interests in world cities } \\
\text { through routinized relations between labor, land, capital, and knowledge markets } \\
\text { - Hierarchization of spaces as necessary or contingent for APS practice }\end{array}$ \\
\hline
\end{tabular}




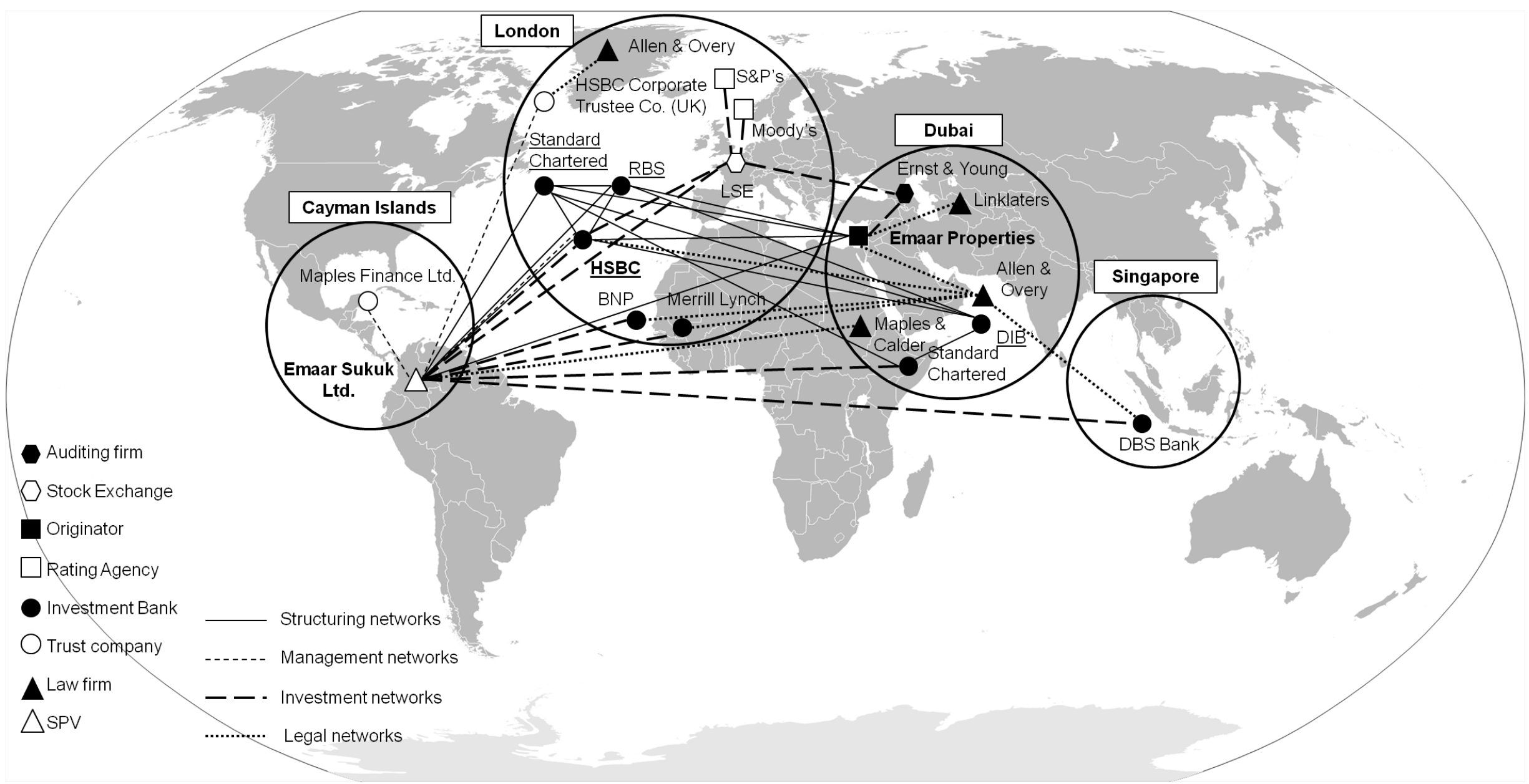

Figure 1 Spaces of dependence and engagement in the issuance process of the Emaar Sukuk 


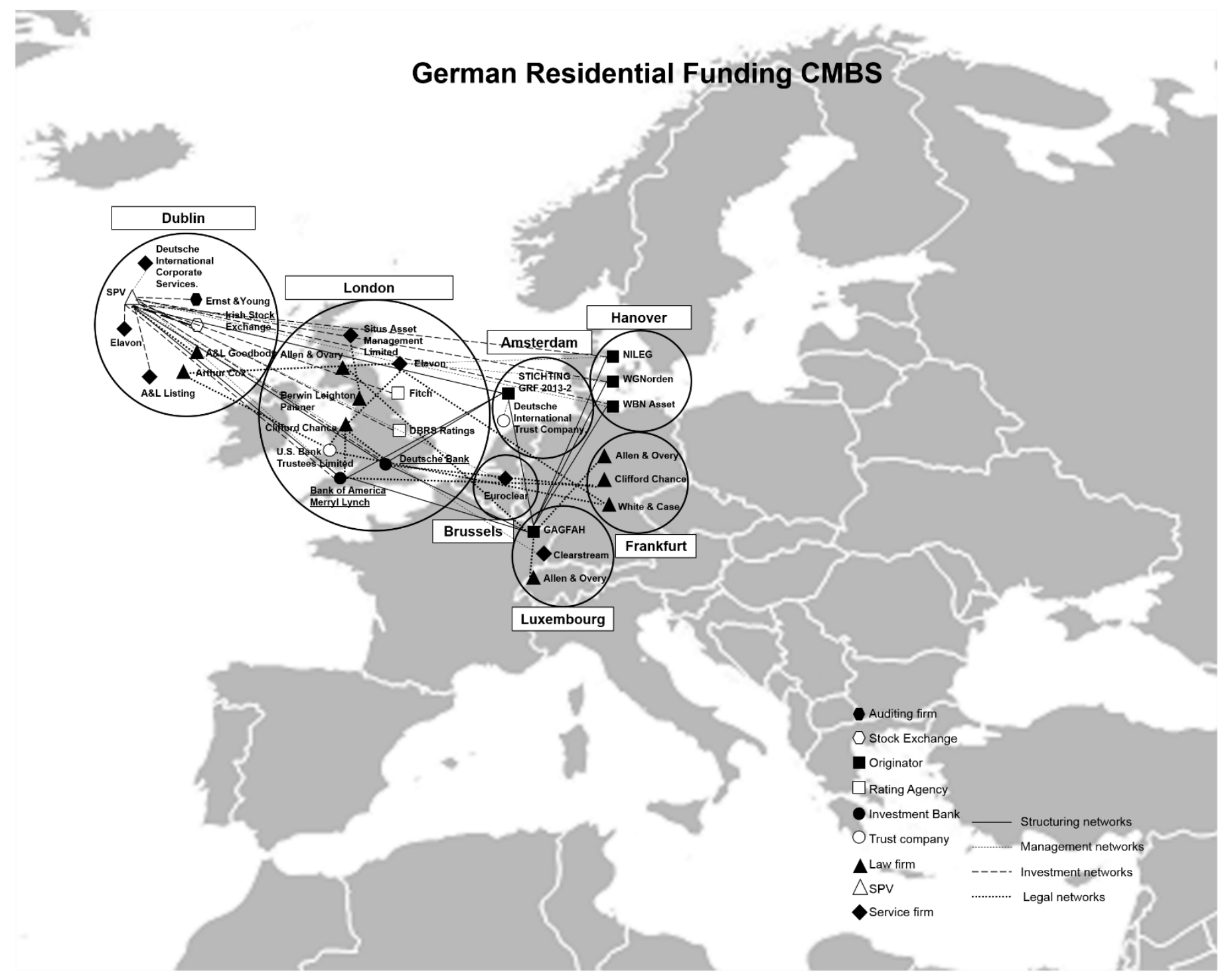

Figure 2 Spaces of dependence and engagement in the issuance process of the German Residential Funding CMBS 


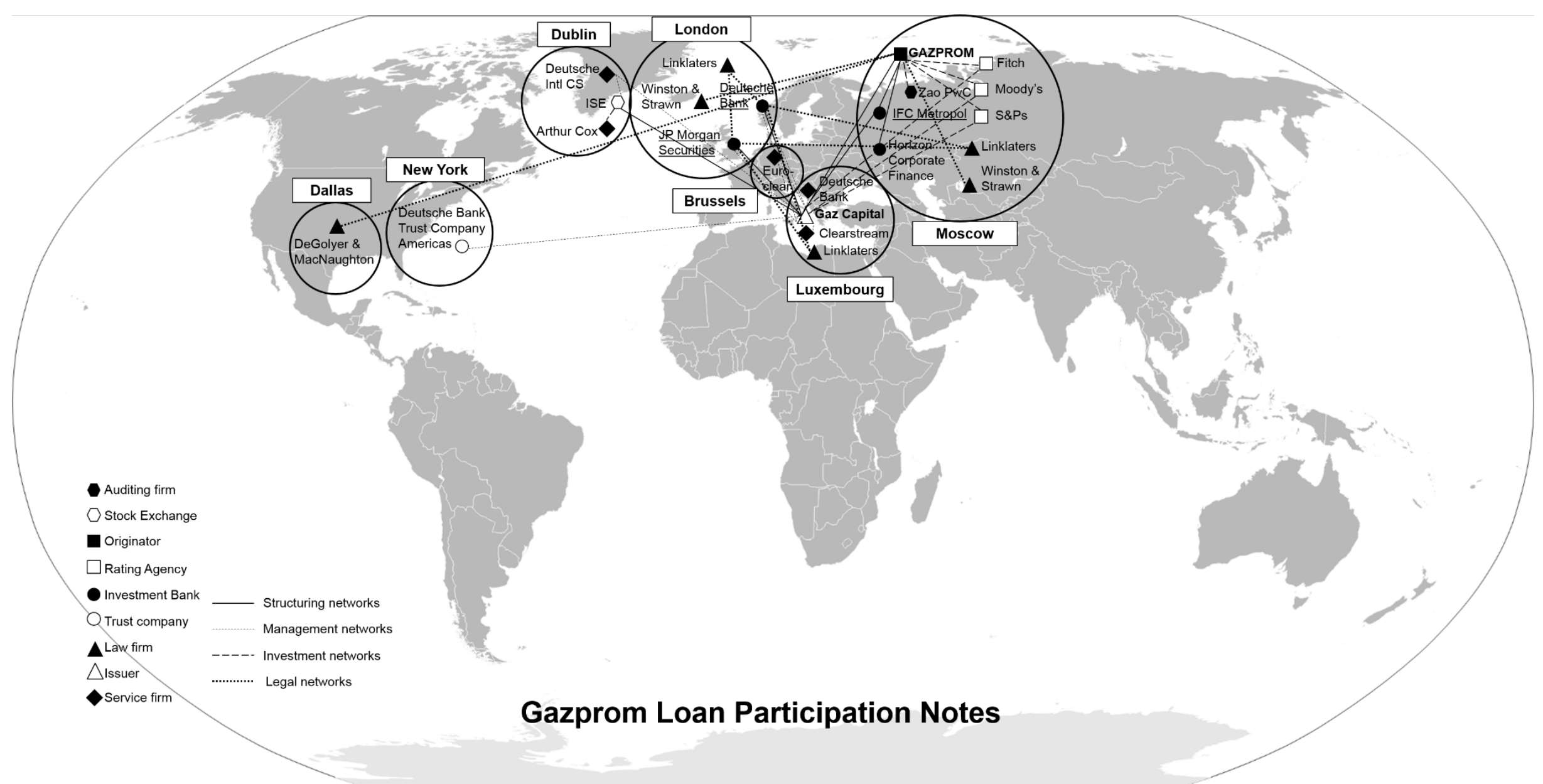

Figure 3 Spaces of dependence and engagement in the issuance process of the Gazprom Loan Participation Notes 